\title{
Adsorption of Cd(II) on Waste Calcite Produced by the Carbonation of Flue Gas Desulfurization (FGD) Gypsum
}

\author{
Kyungsun Song ${ }^{1,2}$, Wonbaek Kim ${ }^{1}$, Taegong Ryu ${ }^{1}$, Kyung-Won Ryu ${ }^{1}$, \\ Jun-Hwan Bang ${ }^{1}$ and Young-Nam Jang ${ }^{1, *}$ \\ ${ }^{1}$ Korea Institute of Geoscience \& Mineral Resources (KIGAM), Gwahang-no 92, Yuseong-gu, Daejeon, 305 350, Korea \\ ${ }^{2}$ Department of Earth System Sciences, Yonsei University, Shinchon-dong 134, Seodaemun-gu, Seoul 120 749, Korea
}

\begin{abstract}
The waste calcite, by-product of the carbonation reaction of flue gas desulfurization (FGD) gypsum, was evaluated as low-cost adsorbent for $\mathrm{Cd}(\mathrm{II})$ removal from wastewater. Batch experiments were performed in aqueous solution varying contact time, initial pH of Cd(II) solution, adsorbent dose, and $\mathrm{Cd}$ (II) concentration. The sorption rate of $\mathrm{Cd}(\mathrm{II})$ on the adsorbent was high during initial $1 \mathrm{~h}$ and decreased slowly reaching a plateau after about $12 \mathrm{~h}$. The adsorption kinetics of Cd(II) could be best described by the pseudo-second order model while its isotherm was found to fit with the Langmuir model. The maximum adsorption capacity was $7.99 \mathrm{mg} \mathrm{g}^{-1}$. It is believed that waste calcite would be an addition to the list of low-cost adsorbents for Cd(II) removal in wastewater treatment. [doi:10.2320/matertrans.M2010344]
\end{abstract}

(Received October 4, 2010; Accepted November 15, 2010; Published December 29, 2010)

Keywords: flue gas desulfurization (FDG) gypsum, cadmium, low-cost adsorbent, calcite

\section{Introduction}

In Korea, more than 2,000 mines out of about 2,500 are now closed and a large amount of them was neglected without control. ${ }^{1)}$ Soil and water contamination by toxic metals streaming from wastes at abandoned mines has recently brought public concerns: rice contaminated with cadmium (Cd) was monitored in Gyeongnam province located in the southern part in Korea and its source point was assumed as an abandoned Bongsan gold mine in this area. ${ }^{2} \mathrm{Cd}$ is highly toxic and readily absorbed by plants, corps, or soil animals, and could be easily ingested to human through the food chain. ${ }^{3)}$ Likewise, Yan et al. ${ }^{4)}$ demonstrated that wastewater discharged from an mine area is strongly associated with $\mathrm{Cd}$ contamination in soil-rice system in Lechang, China.

In order to remove heavy metals in wastewater treatment systems, a variety of techniques including ion exchange or solvent extraction have been developed but adsorption method is conventionally employed with the advantage of being cost-effective and efficient. The activated carbon is the most widely used adsorbent because of its high surface area for Cd removal ${ }^{5,6)}$ but lowering the cost is always the challenge for waste management. Many studies have been performed to seek inexpensive alternative adsorbents for $\mathrm{Cd}$ removal using natural or industrial wastes. ${ }^{7-9)}$

Gypsum is produced as a byproduct from flue gas desulfurization (FGD) systems which are applied to control $\mathrm{SO}_{x}$ gas at coal-fired power plants. It is known as FGD gypsum and its annual worldwide production reaches approximately 7 million tons per year. ${ }^{10)}$ It was landfilled as waste but its potential use for synthesis of ammonium sulfate (a fertilizer) has been applied: ${ }^{11,12}$

$$
\begin{aligned}
& \mathrm{CaSO}_{4} \cdot 2 \mathrm{H}_{2} \mathrm{O}+\mathrm{CO}_{2}+2 \mathrm{NH}_{3} \\
& \quad \rightarrow \mathrm{CaCO}_{3}+\left(\mathrm{HN}_{4}\right)_{2} \mathrm{SO}_{4}+\mathrm{H}_{2} \mathrm{O}
\end{aligned}
$$

After reaction (1), ammonium sulfate exists in the dissolved form in aqueous solution and powdered calcium carbonate can be separated by filtering. This waste calcium carbonate is known to carry impurities which are retained in FGD gypsum. $^{12)}$

Calcite is considered to play an important role as an adsorbent of divalent metals in calcareous soils and groundwater. ${ }^{13)}$ Cadmium among other divalent metals is known to be high sorption affinity for calcite, and it is attributed to a similar ionic radius $(0.095 \mathrm{~nm})$ of $\mathrm{Cd}(\mathrm{II})$ compared to that of $\mathrm{Ca}$ (II) $(0.100 \mathrm{~nm}) .{ }^{14)}$ Some studies have been performed to evaluate the sorption capability of calcite for $\mathrm{Cd}(\mathrm{II})$ removal in wastewater. ${ }^{15-17)}$ The aim of this study is to investigate the potential of the waste calcite obtained by the reaction of FGD gypsum and $\mathrm{CO}_{2}$ as an adsorbent for cadmium removal in contaminated waters.

\section{Materials and Methods}

\subsection{Preparation of adsorbent}

FGD gypsum was obtained from Yeongheung Thermal Power Plants, Incheon, Korea and dried at $60^{\circ} \mathrm{C}$ overnight and sieved through 200 mesh $(74 \mu \mathrm{m})$ for carbonation. FGD gypsum reacted with $\mathrm{CO}_{2}$ gas $(15 \%)$ of a flow rate of $10 \mathrm{~L} \mathrm{~min}^{-1}$ in ammonium hydroxide solution at initial reaction temperature of $50^{\circ} \mathrm{C}$. After the reaction, supernatant ammonium sulfate was filtered and residual waste calcite was dried at $60^{\circ} \mathrm{C}$ overnight.

Crystalline forms and major elements were determined by XRD (X'pert MPD, Philips) using $\mathrm{Cu} / \mathrm{K} \alpha$ radiation and XRF (XRF-1700, Shimadzu), respectively. Particle size distributions were obtained using a laser scattering particle size analyzer (HELOS/RODOS \& SUCELL, Sympatec GmbH). The surface area was determined by the BET method of $\mathrm{N}_{2}$ gas adsorption (ASAP 2010, Micromeritics). For the point of zero charge $\left(\mathrm{pH}_{\mathrm{pzc}}\right)$ of the adsorbent, defined as the point where $\Delta \mathrm{pH}\left(\mathrm{pH}_{\text {equilibrium }}-\mathrm{pH}_{\text {initial }}\right)=0$, a method previously reported was used as follows. ${ }^{18)} 45 \mathrm{~mL}$ of $10 \mathrm{mM} \mathrm{NaCl}$ 
(background electrolyte) was transferred to a series of 50-ml conical tubes. The range of initial $\mathrm{pH}\left(\mathrm{pH}_{\text {initial }}\right)$ values for these solutions was adjusted to $2-12$ by adding either $\mathrm{HCl}$ $(0.01,0.05$, or $0.1 \mathrm{mM})$ or $\mathrm{NaOH}(0.01,0.05$, or $0.1 \mathrm{mM})$. The total volume of the flask was adjusted to $50 \mathrm{~mL}$ by further addition of $10 \mathrm{mM} \mathrm{NaCl}$. Afterwards $0.1 \mathrm{~g}$ of the adsorbent was added. The suspensions were shaken for 2 days and the $\mathrm{pH}$ was measured after centrifuging at 5,000 rpm for $5 \mathrm{~min}$.

\subsection{Preparation of cd(II) solution}

All chemicals (ACS grade) were purchased from SigmaAldrich and used without further purification. $\mathrm{Cd}(\mathrm{II})$ stock solution $\left(1,000 \mathrm{mg} \mathrm{L}^{-1}\right)$ was prepared by dissolving $\mathrm{CdCl}_{2}$ in deionized water purified using a Milli-Q $18 \mathrm{M} \Omega-\mathrm{cm}$ system. The desired Cd(II) concentrations in the solution were prepared by the dilution of the stock solution $(\mathrm{pH}=$ $5.8 \pm 0.1)$.

The Cd(II) solution was analyzed using ICP-OES after filtering through a $0.2 \mu \mathrm{m}$ membrane filter (cellulose acetate, Sartorius) and acidifying with instrumental grade $\mathrm{HNO}_{3}$. The analytical detection limit for metal cations was $0.02 \mathrm{mg} \mathrm{L}^{-1}$ and uncertainty was less than $15 \%$ with replicates.

\subsection{Experimental operations}

All sorption experiments were performed in triplicate and constant ionic strength was maintained using $10 \mathrm{mM} \mathrm{NaCl}$. The equilibrium time and adsorption kinetics were determined using $100 \mathrm{mg} \mathrm{L}^{-1}$ of $\mathrm{Cd}(\mathrm{II})(500 \mathrm{~mL})$ solution and an adsorbent dosage of $10 \mathrm{~g} \mathrm{~L}^{-1}$ for $48 \mathrm{~h}$ at a temperature of $25 \pm 1^{\circ} \mathrm{C}$ in which the solution $\mathrm{pH}$ was not adjusted. The suspension was stirred at $150 \mathrm{rpm}$ with a stir bar and $15 \mathrm{~mL}$ aliquot was withdrawn after pre-determined duration. The initial and final $\mathrm{pH}$ was 6.6 and 7.8, respectively.

The effect of $\mathrm{pH}$ on adsorption was investigated as a function of initial $\mathrm{pH}$ of solution. An equivalent amount of adsorbent $\left(10 \mathrm{~g} \mathrm{~L}^{-1}\right)$ was added to prepare $\mathrm{Cd}(\mathrm{II})$ solutions (100 $\left.\mathrm{mg} \mathrm{L}^{-1}, 100 \mathrm{~mL}\right)$. The $\mathrm{pH}$ values of these solutions were adjusted to $4-11$ at one unit intervals with less than $1 \%$ of the solution volume of $\mathrm{HCl}(0.01,0.05$, or $0.1 \mathrm{M})$ or $\mathrm{NaOH}$ $(0.01,0.05,0.1,0.5$, or $1.0 \mathrm{M})$. All samples were shaken in a temperature-controlled shaker at $150 \mathrm{rpm}$ and $25.0 \pm 0.2^{\circ} \mathrm{C}$ for $24 \mathrm{~h}$.

The adsorbent dose was varied from 2.5 to $40 \mathrm{~g} \mathrm{~L}^{-1}$ in an aqueous solution containing $100 \mathrm{mg} \mathrm{L}^{-1} \mathrm{Cd}(\mathrm{II})(100 \mathrm{~mL})$ while a temperature-controlled shaker was maintained at $150 \mathrm{rpm}$. The reaction temperature was maintained at $25.0 \pm$ $0.2^{\circ} \mathrm{C}$ throughout the experiments.

Experiments varying initial $\mathrm{Cd}(\mathrm{II})$ concentration in the solution were also carried out to obtain the sorption equilibrium data. The $\mathrm{Cd}(\mathrm{II})$ concentration was varied from 20 to $200 \mathrm{mg} \mathrm{L}^{-1}(100 \mathrm{~mL})$ with $20 \mathrm{mg} \mathrm{L}^{-1}$ increments and the adsorbent dose was fixed at $10 \mathrm{~g} \mathrm{~L}^{-1}$. All samples were shaken for $24 \mathrm{~h}$ in a temperature-controlled shaker at $150 \mathrm{rpm}$.

\section{Results and Discussion}

The particle size of the adsorbent ranged from 1 to $100 \mu \mathrm{m}$ with volume mean diameter (VMD) of $4.37 \mu \mathrm{m}$ and the BET specific surface area was $3.76 \mathrm{~m}^{2} \mathrm{~g}^{-1}$. The adsorbent
Table 1 Chemical composition of the waste calcite obtained by $\mathrm{CO}_{2}$ capture using flue gas desulfurization (FGD) gypsum.

\begin{tabular}{lc}
\hline Chemical composition & Value (mass $\%)$ \\
\hline $\mathrm{CaO}$ & 51.64 \\
$\mathrm{SO}_{3}$ & 4.63 \\
$\mathrm{SiO}_{2}$ & 1.91 \\
$\mathrm{Al}_{2} \mathrm{O}_{3}$ & 0.85 \\
$\mathrm{MgO}$ & 0.57 \\
$\mathrm{Fe}_{2} \mathrm{O}_{3}$ & 0.41 \\
$\mathrm{~K}_{2} \mathrm{O}$ & 0.31 \\
$\mathrm{Na}_{2} \mathrm{O}$ & 0.04 \\
$\mathrm{TiO}_{2}$ & 0.03 \\
$\mathrm{P}_{2} \mathrm{O}_{5}$ & 0.02 \\
$\mathrm{MnO}$ & $<0.01$ \\
$\mathrm{Ignition}$ loss & 39.59 \\
\hline
\end{tabular}

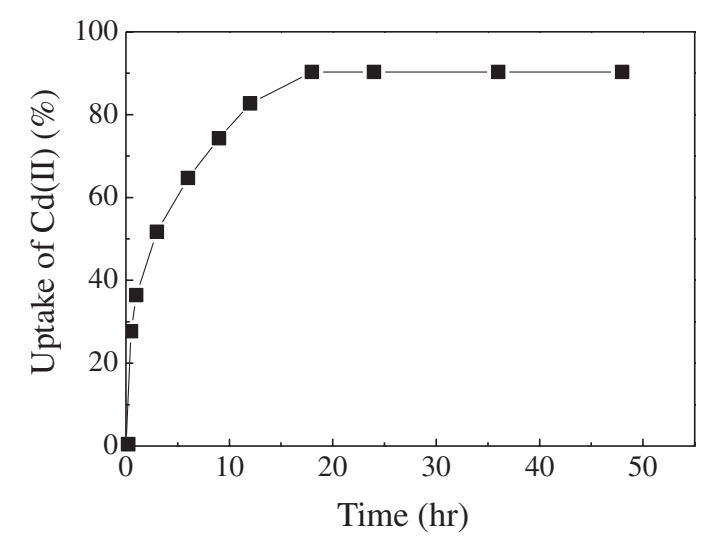

Fig. 1 Uptake of $\mathrm{Cd}(\mathrm{II})\left(100 \mathrm{mg} \mathrm{L}^{-1}\right)$ by the adsorbent $\left(10 \mathrm{~g} \mathrm{~L}^{-1}\right)$ as a function of time.

was mainly composed of calcite with a small amounts of bassanite, dolomite, and muscovite. Table 1 summarizes the result of XRF analysis. The content of calcium was 51.64 mass\% of in oxide form. The point of zero charge, $\Delta \mathrm{pH}\left(\mathrm{pH}_{\text {initial }}-\mathrm{pH}_{\text {final }}\right)=0$, was 8.8 . This value is consistent with the $\mathrm{pH}_{\mathrm{zpc}}$ of calcite $\left(\mathrm{pH}_{\mathrm{zpc}}=8.5-9.5\right)$, as previously reported by Somasundaran and Agar. ${ }^{19)}$ However, heavy metals other than $\mathrm{Cd}$ were not detected in filtrate solution after sorption.

\subsection{Effect of adsorbent-sorbate contact time}

Figure 1 shows the uptake of $\mathrm{Cd}$ (II) by the adsorbent as a function of time. The initial concentration of metal was $100 \mathrm{mg} \mathrm{L}^{-1}$ in $500 \mathrm{~mL}$ with an adsorbent to aqueous solution ratio of $10 \mathrm{~g} \mathrm{~L}^{-1}$. Here, initial $\mathrm{pH}$ was 6.6 and additional adjustment was not made during the reaction. The adsorption was very fast initially removing about $36 \%$ of total Cd(II) in $1 \mathrm{hr}$. It increased slowly afterwards reaching a plateau value after about $18 \mathrm{hr}$. This agrees with the results of Davies et $a l .{ }^{20)}$ They observed rapid uptake of $\mathrm{Cd}(\mathrm{II})$ by calcite during the first step and a slow increase to equilibrium after $24 \mathrm{~h}$. It is obvious that the initial high sorption rate is due to the abundance of accessible sorption sites on the surface. Based on the result, we speculated that the equilibrium conditions were attained in $18 \mathrm{~h}$. 


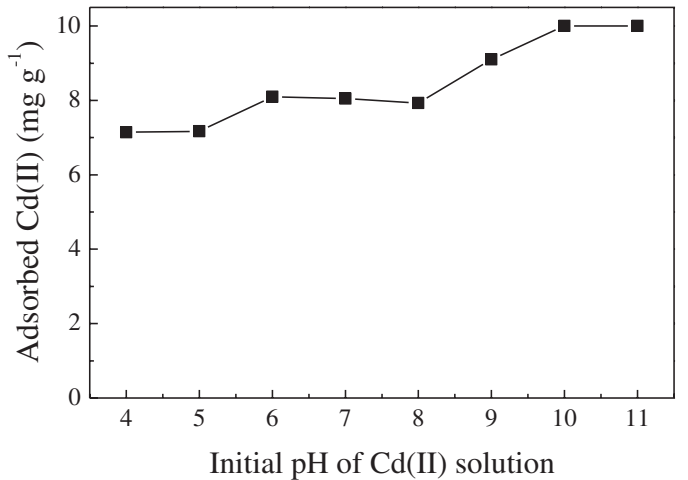

Fig. $2 \mathrm{Cd}(\mathrm{II})$ adsorption by the adsorbent $\left(10 \mathrm{~g} \mathrm{~L}^{-1}\right)$ as a function of the initial $\mathrm{pH}$ of the $\mathrm{Cd}(\mathrm{II})$ solution.

\subsection{Effect of solution pH}

It is known that $\mathrm{pH}$ has a significant influence on metal sorption by affecting protonation or deprotonation of adsorbate as well as adsorbent. However, the assessment of $\mathrm{pH}$ effects by conventional methods was not possible in this study due to the rapid degradation of calcite-water equilibrium in an open system. Therefore, we adopted another method reported earlier, ${ }^{9)}$ in which a calcite-rich adsorbent was used. The adsorbent $\left(10 \mathrm{~g} \mathrm{~L}^{-1}\right)$ was added to $\mathrm{Cd}$ (II) solutions $\left(100 \mathrm{mg} \mathrm{L}^{-1}, 100 \mathrm{~mL}\right)$ of which initial $\mathrm{pH}$ was fixed at the desired values (from 4 to 11 ) in advance. Although the removal of cadmium ions in the aqueous solution may proceeds gradually by increasing the initial $\mathrm{pH}$ of the solution, the effect was not significant as demonstrated in Fig. 2. From the results, cadmium uptake reached $70 \%$ at a low $\mathrm{pH}$ range of $4.0-5.0$, around $80 \%$ at a $\mathrm{pH}$ between 6.0 and $8.0,90 \%$ at $\mathrm{pH} 9$, and a maximum of $100 \%$ at $\mathrm{pH}$ higher than 9. It was observed that when the adsorbent was put into the solution the $\mathrm{pH}$ of which was fixed initially in the $\mathrm{pH}$ range of $4.0-6.0$, the $\mathrm{pH}$ shifted rapidly to around circumneutral value $(\sim 7.0)$. In view of this observation, the fact that $\mathrm{Cd}$ (II) removal efficiency was high even at lower $\mathrm{pH}$ as 4.0-5.0 can be attributed to $\mathrm{pH}$ increase resulted from the dissolution of calcite as follows:

$$
\begin{aligned}
& \mathrm{CaCO}_{3} \rightarrow \mathrm{Ca}^{2+}+\mathrm{CO}_{3}^{2-} \\
& \mathrm{CO}_{3}{ }^{2-} \rightarrow \mathrm{HCO}_{3}{ }^{-}+\mathrm{OH}^{-}
\end{aligned}
$$

Wang et al. ${ }^{9)}$ showed a diagram of $\mathrm{Cd}(\mathrm{II})$ species distribution in the presence of calcite in an open system: The maximum amount of $\mathrm{CdCO}_{3}$ precipitation was $17 \%$ at $\mathrm{pH} 9.5$ and $\mathrm{Cd}(\mathrm{OH})_{2} 30$ to $90 \%$ at $\mathrm{pH}$ range of $10-11$. Therefore, it is obvious that $\mathrm{Cd}(\mathrm{II})$ precipitation as $\mathrm{CdCO}_{3}$ or $\mathrm{Cd}(\mathrm{OH})_{2}$ may participate in the $\mathrm{Cd}(\mathrm{II})$ removal in higher $\mathrm{pH}$ range than 9. However, further investigation on the precipitation effect was not the scope of the present study.

\subsection{Effect of adsorbent dosage}

Determination of appropriate amount of adsorbent dosage is of consequence in sorption processes. Figure 3 shows the effect of adsorbent dosage on the removal of $\mathrm{Cd}$ (II) in aqueous solution. At the fixed concentration of $\mathrm{Cd}(\mathrm{II})$ (100 $\left.\mathrm{mg} \mathrm{L}^{-1}, 100 \mathrm{~mL}\right)$, adsorbent dose was changed from 2.5 to $40 \mathrm{~g} \mathrm{~L}^{-1}$ in an aqueous solution. The percentage of $\mathrm{Cd}(\mathrm{II})$ uptake increased in the adsorbent dosage range of 2.5

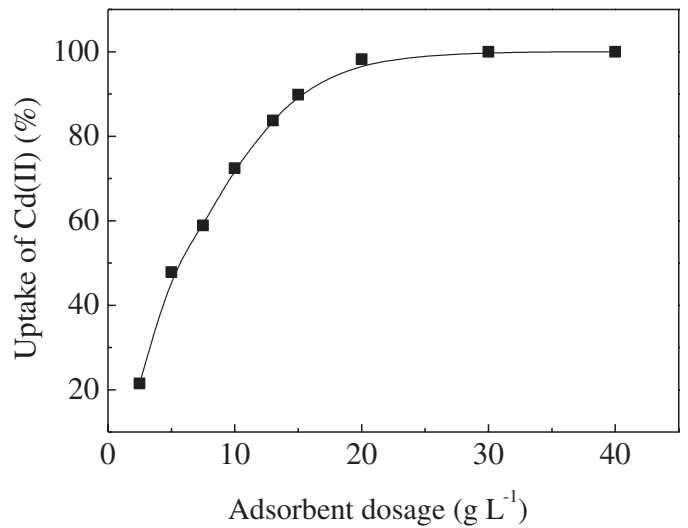

Fig. 3 Uptake of Cd(II) (100 $\left.\mathrm{mg} \mathrm{L}^{-1}\right)$ as a function of adsorbent dose (2.5$\left.40 \mathrm{~g} \mathrm{~L}^{-1}\right)$.

to $20 \mathrm{~g} \mathrm{~L}^{-1}$. However, when adsorbent dosage ranged from 20 to $40 \mathrm{~g} \mathrm{~L}^{-1}$, it remained constant closed to $100 \%$. It is obvious that the relationship between the uptake ratio of $\mathrm{Cd}(\mathrm{II})$ and adsorbent results from an increase in the availability of sorption sites (due to the increased surface area of the adsorbent) with increasing adsorbent dose. This is confirmed by the fact $100 \mathrm{mg} \mathrm{L}^{-1}$ of $\mathrm{Cd}(\mathrm{II})$ could be completely removed when more than $20 \mathrm{~g} \mathrm{~L}^{-1}$ of the adsorbent is used.

\subsection{Sorption rate}

The Lagergren pseudo-first order, Ho pseudo-second order, and intraparticle diffusion models have been the most widely used kinetic models to describe sorption experiments. $^{21,22)}$

The pseudo-first order equation of Lagergren is expressed as:

$$
\log \left(q_{\mathrm{e}}-q_{\mathrm{t}}\right)=\log q_{\mathrm{e}}-\left(k_{1} / 2.303\right) t
$$

where $q_{\mathrm{t}}$ and $q_{\mathrm{e}}$ are the amount of cadmium ions adsorbed $\left(\mathrm{mg} \mathrm{g}^{-1}\right)$ at time $t(\mathrm{~min})$ and at equilibrium, respectively. $k_{1}$ is the pseudo-first order reaction rate constant for adsorption $\left(\min ^{-1}\right)$.

The pseudo-second order equation is given as:

$$
t / q_{\mathrm{t}}=t / q_{\mathrm{e}}+1 /\left(k_{2} q_{\mathrm{e}}{ }^{2}\right)
$$

where $q_{\mathrm{t}}$ and $q_{\mathrm{e}}$ are the amount of cadmium ions adsorbed $\left(\mathrm{mg} \mathrm{g}^{-1}\right)$ at time $t$ ( $\left.\mathrm{min}\right)$ and at equilibrium, respectively. $k_{2}$ is the second-order rate constant for adsorption $\left(\mathrm{g} \mathrm{mg}^{-1}\right.$ $\min ^{-1}$ ).

The initial rate of intraparticle diffusion $\left(k_{\mathrm{d}}\right)$ can be calculated according to the following equation:

$$
q_{\mathrm{t}}=k_{\mathrm{d}} t^{0.5}
$$

where $q_{\mathrm{t}}$ is the amount of cadmium ions adsorbed at time $t\left(\mathrm{mg} \mathrm{g}^{-1}\right), k_{\mathrm{d}}$ is the intraparticle rate constant $\left(\mathrm{mg} \mathrm{g}^{-1} \min ^{-0.5}\right)$ and $t$ is the time (min).

Figure 4(a) and (b) show the fitting line obtained by plotting $\log \left(q_{\mathrm{e}}-q_{\mathrm{t}}\right)$ and $t / q_{\mathrm{t}}$ against $t$ for the pseudo-first order kinetic model in eq. (4) and pseudo-second-order kinetic model in eq. (5), respectively. From these lines, $k_{1}$, $k_{2}, q_{\mathrm{e}}$, and correlation coefficients of $R^{2}$ were calculated and presented on each graph. It can be seen that the pseudo- 

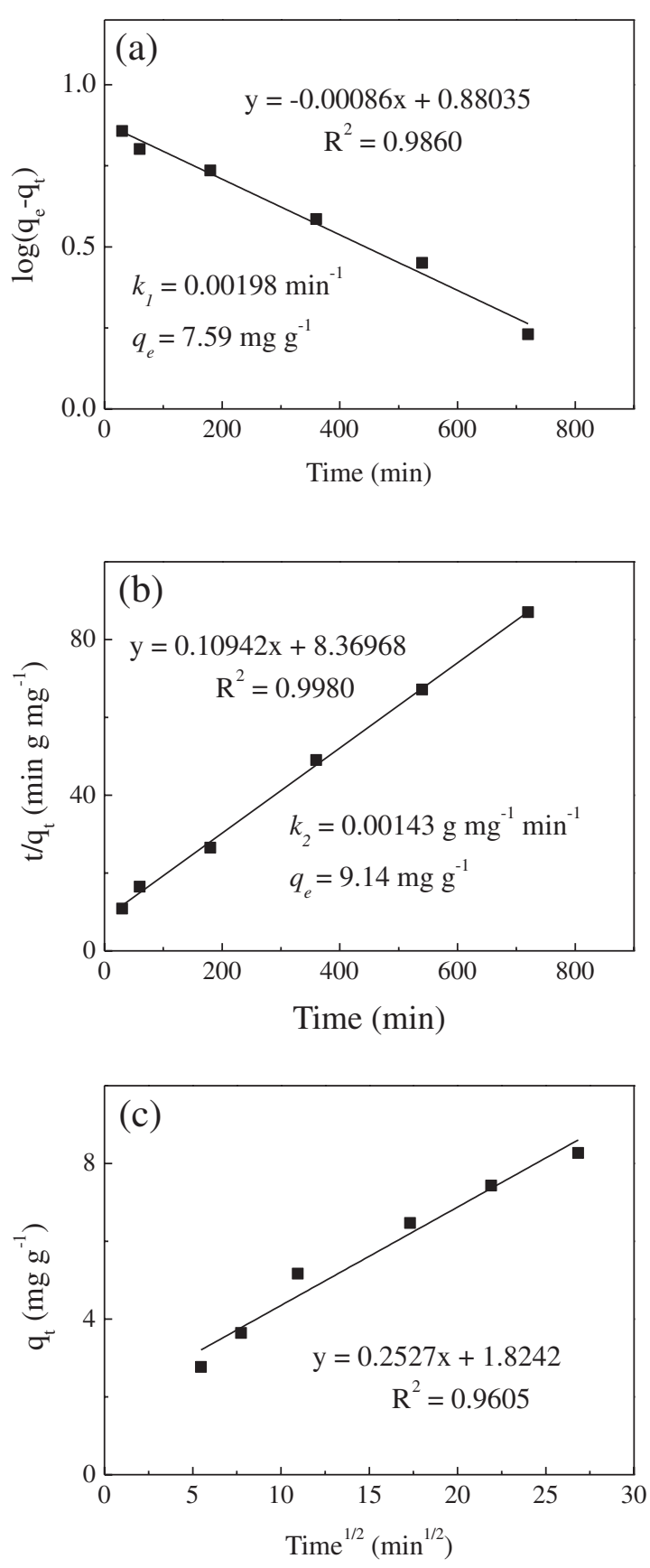

Fig. 4 Linear fit of experimental data using (a) pseudo first-order kinetic model, (b) pseudo second-order kinetic model, and (c) intraparticle diffusion model for the adsorption of Cd(II) sorption.

second order kinetic model fits better $\left(R^{2}=0.9980\right)$ with the experimental data than the pseudo-first order model $\left(R^{2}=0.9860\right)$. In addition, the amount of $\mathrm{Cd}(\mathrm{II})$ at equilibrium, $q_{\mathrm{e}}$, based on the pseudo-second order kinetic model $\left(9.14 \mathrm{mg} \mathrm{g}^{-1}\right)$ also agrees with the experimental result $\left(9.04 \mathrm{mg} \mathrm{g}^{-1}\right)$. It is known that chemical interaction (chemical sorption) is involved when sorption data fits the pseudosecond order kinetic model. ${ }^{23}$ ) Meanwhile, as shown in Fig. 4(c), it does not fit the intraparticle diffusion model. The correlation coefficient and an intercept are 0.9605 and 1.8242 , respectively. Above results suggest that the sorption of $\mathrm{Cd}(\mathrm{II})$ on the adsorbent follows pseudo-second order kinetic but is not controlled by intraparticle diffusion.

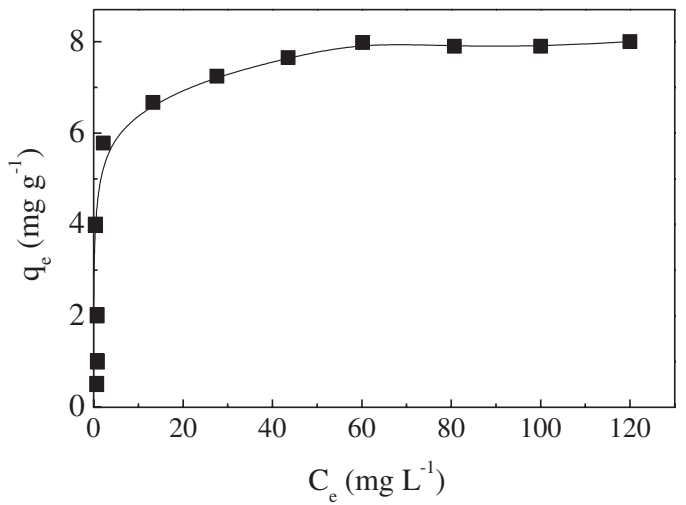

Fig. 5 Effect of the initial concentration of $\mathrm{Cd}(\mathrm{II})\left(20-200 \mathrm{mg} \mathrm{L}^{-1}\right)$ on $\mathrm{Cd}$ (II) sorption by the adsorbent $\left(10 \mathrm{~g} \mathrm{~L}^{-1}\right)$.

\subsection{Sorption isotherms}

The sorption equilibrium was studied to understand the mechanism of $\mathrm{Cd}(\mathrm{II})$ sorption on the adsorbent. Figure 5 depicts the uptake of $\mathrm{Cd}(\mathrm{II})$ per unit mass of adsorbent, $q_{\mathrm{e}}$, versus the $\mathrm{Cd}(\mathrm{II})$ concentration in solution at equilibrium when the initial $\mathrm{Cd}(\mathrm{II})$ concentration was ranged from 20 to $200 \mathrm{mg} \mathrm{L}^{-1}$ at a fixed adsorbent dose $\left(10 \mathrm{~g} \mathrm{~L}^{-1}\right)$. As shown Fig. 5, the equilibrated amount of $\mathrm{Cd}(\mathrm{II})$ increased with the initial concentration of metal ion reaching a maximum value at about $8 \mathrm{mg} \mathrm{g}^{-1}$.

The experimental data were examined with Langmuir and Freundlich sorption isotherm models. The Langmuir model assumes a homogeneous monolayer sorption of adsorbate on an adsorbent having a finite number of sorption sites, which are independent and equivalent. Its linear form can be written as eq. (7). On the other hand, the Freundlich model assumes a non-ideal multilayer sorption having infinite surface coverage, in which both exponential distribution of active sites and mutual interaction between adsorbed molecules are possible. The linear form can be expressed as eq. (8).

$$
\begin{aligned}
& C_{\mathrm{e}} / q_{\mathrm{e}}=1 /\left(b q_{\max }\right)+C_{\mathrm{e}} / q_{\max } \\
& \ln q_{\mathrm{e}}=\ln K+1 / n\left(\ln C_{\mathrm{e}}\right)
\end{aligned}
$$

where $q_{\mathrm{e}}$ and $C_{\mathrm{e}}$ represent the $\mathrm{Cd}(\mathrm{II})$ concentration per unit mass of adsorbent and solution at equilibrium, $K$ is the Freundlich constant related to the sorption capacity, $q_{\max }$ is the maximum adsorption capacity, and $b$ and $n$ are constants for the adsorption energy.

The adsorption constants of Langmuir and Freundlich equation and their correlation coefficients $\left(R^{2}\right)$ are presented on the Fig. 6. It is seen that Langmuir model $\left(R^{2}=0.9993\right)$ fits better than Freundlich model $\left(R^{2}=0.9829\right)$. This suggests that $\mathrm{Cd}(\mathrm{II})$ adsorption occurs in the form of monolayer coverage. The maximum adsorption capacity for $\mathrm{Cd}(\mathrm{II}), q_{\max }$, was calculated as $7.99 \mathrm{mg} \mathrm{g}^{-1}$ using Langmuir equation which agrees to the measured value.

In previous studies, ${ }^{15,16,24,25)}$ the maximum $\mathrm{Cd}(\mathrm{II})$ uptake of different calcite minerals varies widely from 0.26 to $18.5 \mathrm{mg} \mathrm{g}^{-1}$. This suggests that the maximum uptake depends greatly not only on the nature of calcite minerals as chemistry and crystal structure but also on the reaction conditions as $\mathrm{pH}$, ionic strength, initial concentration of adsorbate, the ratio of adsorbent dosage to aqueous solution etc. Therefore, it is 

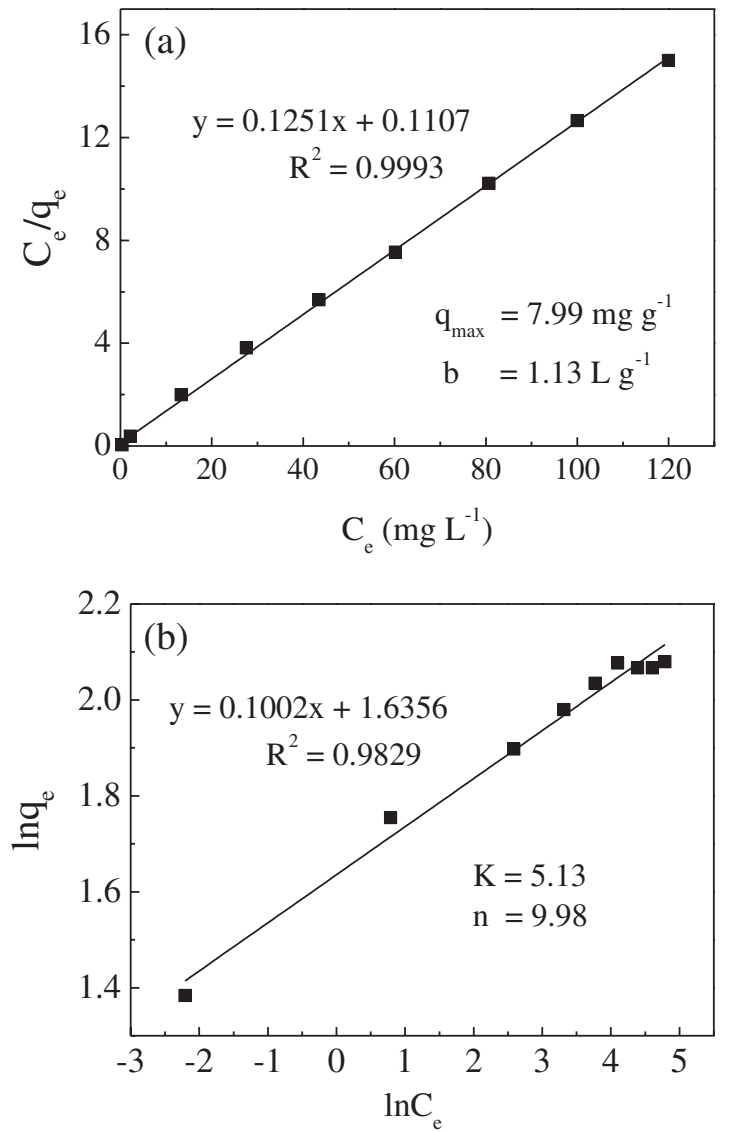

Fig. 6 Langmuir (a) and Freundlich (b) isotherms of Cd(II) sorption on the adsorbent $\left(10 \mathrm{~g} \mathrm{~L}^{-1}\right)$ in the $\mathrm{Cd}(\mathrm{II})$ concentration range of $20-200 \mathrm{mg} \mathrm{L}^{-1}$.

obvious that more research is needed to clarify and to enhance the maximum uptake of Cd(II). Nevertheless, it is clearly demonstrated that the waste calcite would be an economically and environmentally promising adsorbent for Cd(II).

\section{Conclusions}

The sorption behavior of $\mathrm{Cd}(\mathrm{II})$ on the waste calcite, obtained by the reaction of FGD gypsum $\mathrm{CO}_{2}$, was investigated by varying parameters as adsorbent dose, $\mathrm{pH}$, reaction time, and $\mathrm{Cd}(\mathrm{II})$ concentration. The results can be summarized as follows:

(1) The percentage of removed $\mathrm{Cd}(\mathrm{II})\left(100 \mathrm{mg} \mathrm{g}^{-1}\right)$ increased with an increase in the adsorbent dose. A dose higher than $20 \mathrm{~g} \mathrm{~L}^{-1}$ was required to completely remove $100 \mathrm{mg} \mathrm{L}^{-1} \mathrm{Cd}(\mathrm{II})$.

(2) The effect of initial $\mathrm{pH}$ of solution on $\mathrm{Cd}(\mathrm{II})$ sorption was insignificant because the solution $\mathrm{pH}$ was adjusted immediately to a circumneutral value with the addition of the adsorbent regardless of initial $\mathrm{pH}$ which was between 4 and 8 . At $\mathrm{pH}$ higher than $9, \mathrm{Cd}(\mathrm{II})$ precipitation may also participate in the sorption.

(3) The sorption rate was high during initial $1 \mathrm{~h}$ and decreased slowly until it reaches a plateau after about $12 \mathrm{~h}$. The time for the equilibrium was about $18 \mathrm{~h}$.

(4) The adsorption kinetics of $\mathrm{Cd}(\mathrm{II})$ could be best described by the pseudo-second order model suggesting that chemical interaction (chemisorption) between adsorbates and adsorbents is involved.

(5) The sorption isotherm was well fitted to the Langmuir adsorption model. The maximum adsorption capacity was $7.99 \mathrm{mg} \mathrm{g}^{-1}$. It is demonstrated that the waste calcite would be an economically and environmentally promising adsorbent for the removal of $\mathrm{Cd}$ (II) from waste water.

\section{Acknowledgements}

This research was supported by the Basic Research Project of the Korea Institute of Geoscience and Mineral Resources (KIGAM) funded by the Ministry of Knowledge Economy of Korea.

\section{REFERENCES}

1) Korea Ministry of Environment: Final Report of Environmental Investigation for Abandoned Mine in Korea, (2005).

2) C. O. Hong, D. K. Lee, D. Y. Chung and P. J. Kim: Arch. Environ. Contam. Toxicol. 52 (2007) 496-502.

3) K. Vig, M. Megharaj, N. Sethunathan and R. Naidu: Adv. Environ. Res. 8 (2003) 121-135.

4) Q. W. Yang, C. Y. Lan, H. B. Wang, P. Zhuang and W. S. Shu: Agr. Water Manage. 84 (2006) 147-152.

5) V. C. Srivastava, I. D. Mall and I. M. Mishra: Chem. Eng. Process. 47 (2008) 1269-1280.

6) A. M. Youssef, Th. El-Nabarawy and S. E. Samra: Colloids Surf. A 235 (2004) 153-163.

7) F. Y. Wang, H. Wang and J. W. Ma: J. Hazard. Mater. 177 (2010) 300306.

8) C. Namasivayam and K. Ranganathan: Water Res. 29 (1995) 17371744.

9) Y. Wang, X. Tang, Y. Chen, L. Zhan, Z. Li and Q. Tang: J. Hazard. Mater. 172 (2009) 30-37.

10) P. A. Ciullo: Chapter 2, The industrial minerals. In Industrial minerals and their uses: a handbook and formulary, (Noyes Publications, 1996) pp. 35-37.

11) M.-I. M. Chou, J. A. Bruinius, V. Benig, S.-F. J. Chou and R. H. Carty: Energy Sources Part A 27 (2005) 1061-1071.

12) W. C. Burnett, M. K. Schultz and C. D. Hull: J. Environ. Radioact. 32 (1996) 33-51.

13) J. M. Zachara, C. E. Cowan and C. T. Resch: Geochim. Cosmochim. Acta 55 (1991) 1549-1562.

14) M. B. McBride: Soil Sci. Soc. Am. J. 44 (1980) 26-28.

15) A. García-Sánchez and E. Álvarez-Ayuso: Miner. Eng. 15 (2002) 539547.

16) Ö. Yavuz, R. Guzel, F. Aydin, I. Tegin and R. Ziyadanogullari: Pol. J. Environ. Stud. 16 (2007) 467-471.

17) M. Lee, I. S. Paik, I. Kim, H. Kang and S. Lee: J. Hazard. Mater. 144 (2007) 208-214.

18) M. Havelcová, J. Mizera, I. Sýkorová and M. Pekař: J. Hazard. Mater. 161 (2009) 559-564.

19) P. Somasundaran and G. E. Agar: J. Colloid Interface Sci. 24 (1967) 433-440.

20) J. A. Davis, C. C. Fuller and A. D. Cook: Geochim. Cosmochim. Acta 51 (1987) 1477-1490.

21) X.-S. Wang, Y. Qin and Z.-F. Li: Sep. Sci. Technol. 41 (2006) 747756.

22) D. Liao, W. Zheng, X. Li, Q. Yang, X. Yue, L. Guo and G. Zeng: J. Hazard. Mater. 177 (2010) 126-130.

23) Y. S. Ho and G. McKay: Process Biochem. 34 (1999) 451-465.

24) M. Shirvani, H. Shariatmadari, M. Kalbasi, F. Nourbakhsh and B. Najafi: Colloids Surf. A 287 (2006) 182-190.

25) M. Prieto, P. Cubillas and Á. Fernández-Gonzalez: Geochim. Cosmochim. Acta 67 (2003) 3859-3869. 